University of Nebraska - Lincoln

DigitalCommons@University of Nebraska - Lincoln

Papers in the Earth and Atmospheric Sciences

Earth and Atmospheric Sciences, Department

12-1939

\title{
NEBRASKA IN RELATION TO THE PROBLEMS OF PLEISTOCENE STRATIGRAPHY
}

Alvin Leonard Lugn

University of Nebraska-Lincoln

Follow this and additional works at: https://digitalcommons.unl.edu/geosciencefacpub

Part of the Earth Sciences Commons

Lugn, Alvin Leonard, "NEBRASKA IN RELATION TO THE PROBLEMS OF PLEISTOCENE STRATIGRAPHY" (1939). Papers in the Earth and Atmospheric Sciences. 358.

https://digitalcommons.unl.edu/geosciencefacpub/358

This Article is brought to you for free and open access by the Earth and Atmospheric Sciences, Department of at DigitalCommons@University of Nebraska - Lincoln. It has been accepted for inclusion in Papers in the Earth and Atmospheric Sciences by an authorized administrator of DigitalCommons@University of Nebraska - Lincoln. 


\title{
American Journal of Science
}

DECEMBER 1939

\section{$\longrightarrow$ \\ NEBRASKA IN RELATION TO THE PROBLEMS OF PLEISTOCENE STRATIGRAPHY. ${ }^{1}$}

\author{
A. L. LUGN.
}

Abstract.

CONTENTS.

Introduction.

Glacial and fluviatile Pleistocene materials in Nebraska.

Age of the Loveland loess.

Pleistocene classification.

Correlation with Europe.

Glacial or interglacial.

Glacial or interglacial loess.

Duration of the glacial advances.

Post-Loveland pre-Peorian erosion.

Geomorphology of the Great Plains and Pleistocene history.

Sources of loess materials.

River valleys and loess deposition.

Dust storms.

The "Citellus" zone.

The problem of animal survival.

Aftonian (?) fauna.

Antiquity of varved sediments.

Conclusions.

ABSTRACT. Nebraska is so peculiarly situated with respect to Pleistocene deposits of glacial, fluviatile, and eolian origin that it holds the key to the solution of many important problems of the stratigraphy of that period. A brief outline of the Pleistocene geology of Nebraska with several illustrations is followed by a statement of and brief discussion of several of these problems. The main problems touched upon are: age of the Loveland loess, Pleistocene classification, correlation with Europe, the need for a better understanding of what is meant by "glacial" and "interglacial," the problem of glacial and interglacial loess, the duration of the glacial advances, post-Loveland pre-Peorian erosion, the geomorphology of the Great Plains as an aid in understanding Pleistocene history, sources of loess materials, the relation of river valleys to the origin and deposition of the loess, the significance of the lesson of the dust storms, the "Citellus" zone and the antiquity of Man, problem of animal survival and Pleistocene faunal succession, what constitutes the Aftonian fauna, and the problems of varved sediments. Pleistocene geology still is in the "experimental" stage.

${ }^{1}$ This paper now completely revised was presented first in brief by Mr. C. Bertrand Schultz in the absence of the writer at the International Symposium on Early Man, Philadelphia Academy of Natural Sciences, March, 1937.

Am. Jour. Sc.-Vol. 237, No. 12, December, 1939. 
$\mathrm{T}$ HE State of Nebraska is peculiarly and fortuitously situated in regard to the deposits of the Great Ice Age which occur within its borders. It has deposits of till of two definitely recognized glaciers, the Nebraskan and the Kansan, in the east; and, west of the till border, great fluviatile sand and gravel sheets are developed in such a manner that they can be correlated with the glacial formations to the east in eastern Nebraska, Iowa, and other areas and with the High Plains terraces along the major drainages to the west, and even with the elevated terrace remnants and peneplains in the Rocky Mountains. Continuous deposits of loess of several ages occur from east to west overlying the older complex of till and fluviatile deposits, and on some of the terrace levels.

It is the purpose of this paper to point out mainly the importance of some of the more significant relationships. Very little if any new research is presented herein for the first time, and no pretense is made to suggest the solutions to all of the problems. The primary aim is to suggest the existence of important and significant relationships and to stimulate interest in the problems for which future research may find the solutions within this State. This paper is presented with full knowledge that it does not contain reports and conclusions on significant new findings pertaining to the several points mentioned. It is avowedly sketchy and intentionally covers a very wide field, perhaps too wide, in order to suggest that the interpretation of Pleistocene stratigraphic and sedimentation history will not be complete until a fuller knowledge and more thorough understanding have been attained of the border relations between strictly glacial, fluviatile, and eolian sediments such as are developed on such a grand scale in this area.

\section{GLACIAL AND FLUVIATILE PLEISTOCENE MATERIALS}

IN NEBRASKA.

The surface of eastern Nebraska, the Dissected Till Plains, is underlain by at least two till sheets and some associated deposits, resting on the bedrock, in this order from below, up: sub-till or early Nebraskan gravel from 20 to 150 feet thick (the David City formation); Nebraskan till and gumbotil up to $\mathbf{1 0 0}$ feet thick, and may attain considerably greater thickness; Aftonian or inter-till sand and gravel 0 to 60 or more 


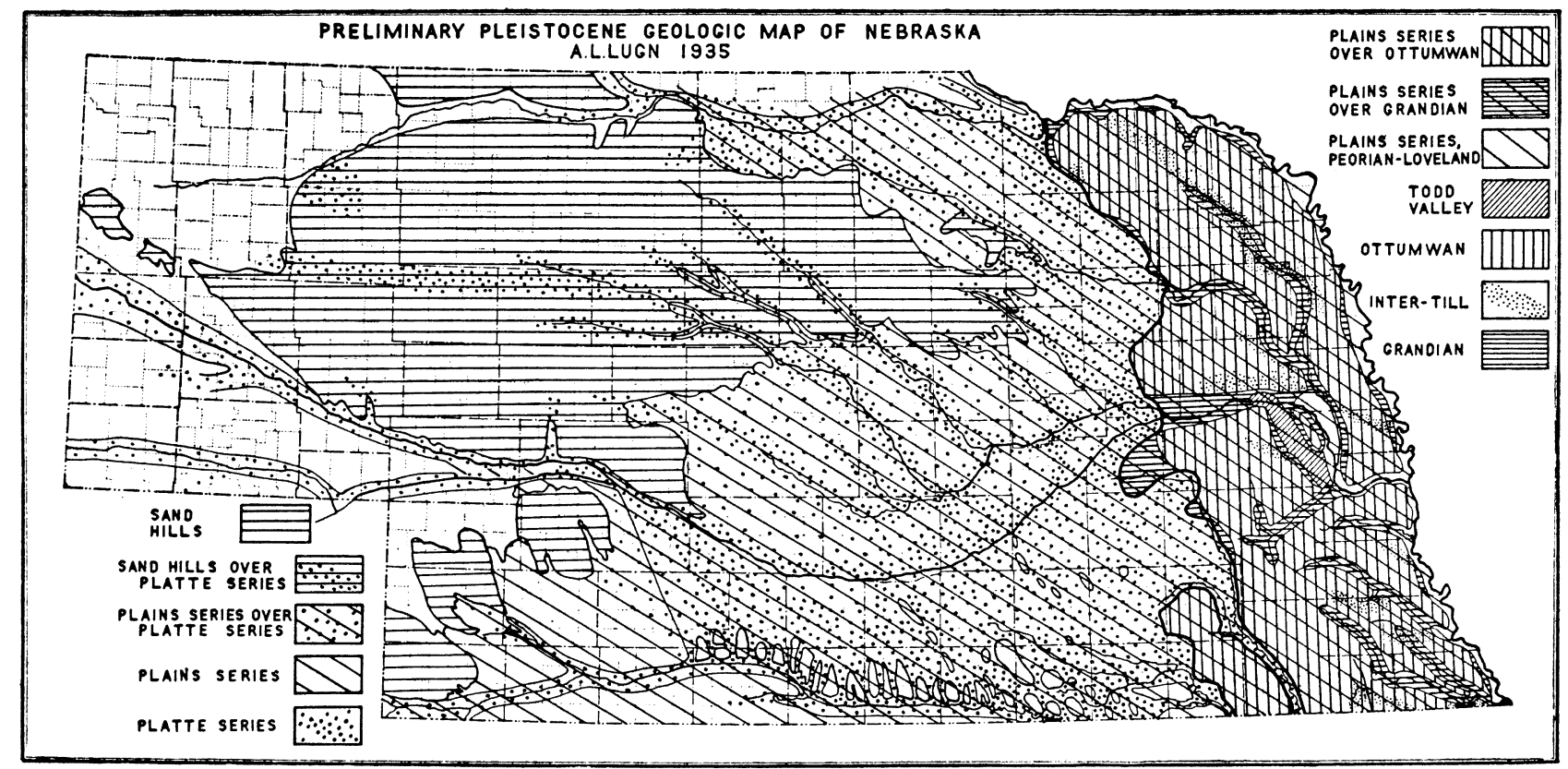

Fig. 1. Pleistocene geologic map of Nebraska. 
feet thick ; Kansan till and gumbotil up to 80 to 100 feet thick; red Loveland gravel, sand, and loess clay up to 30 or more feet thick; yellow and yellowish-gray loess silt and clay, mostly of Peorian age, 15 to 100 or more feet thick. In some places, the deposits of inter-till sand and gravel between the Kansan till and the Nebraskan materials are both extensive and thick. The Kansan till where present, rests on these gravels, or unconformably on the Nebraskan till and gumbotil, which everywhere were greatly eroded before the deposition of either the inter-till sand and gravel or the Kansan till. Likewise, erosion unconformities separate the Loveland deposits from the underlying Kansan till and gumbotil, and the overlying yellowish Peorian loess. Only remnants remain of the two gumbotils that were once extensive. It is significant that the Nebraskan till is thicker and more extensive in this State than the Kansan till. However, in Saline, Jefferson, and Gage counties the Kansan till sheet extends beyond the Nebraskan terminal border and rests on fine-textured Nebraskan inwash-outwash deposits (Holdrege formation), which also contains here a large admixture of locally derived sand from the underlying Dakota sandstones.

The surface of the loess plain of south-central Nebraska, an area of more than 8,000 square miles, west of the till-covered area is underlain by the yellowish Peorian loess and the Loveland formation (the Plains series), which increase in total thickness westward to a maximum of about 300 feet. Under these formations are thick and extensive beds of gravel, sand, silt, and clay, which are the fluvio-glacial outwash from the ice sheets and drift plains to the eastward and the inwash of sediment-laden streams from the High Plains to the west and northwest. Much of this material has been more or less locally derived by the reworking of the High Plains Tertiary formations. These deposits (the Platte series), while intricate in detail, as a whole are comparatively uniform and both extensive and persistent, and they can be correlated with contemporaneous glacial and interglacial formations.

The Loveland formation at many places rests on remnants of a greenish sandy or silty clay, which was once an extensive and continuous bed, but which was largely removed from the old surface by pre-Loveland erosion. This clay or silt formation is thought to represent the lull in sedimentation activity during the Yarmouth interglacial age, and it is known as the Upland formation, five to 35 feet thick. This formation also 


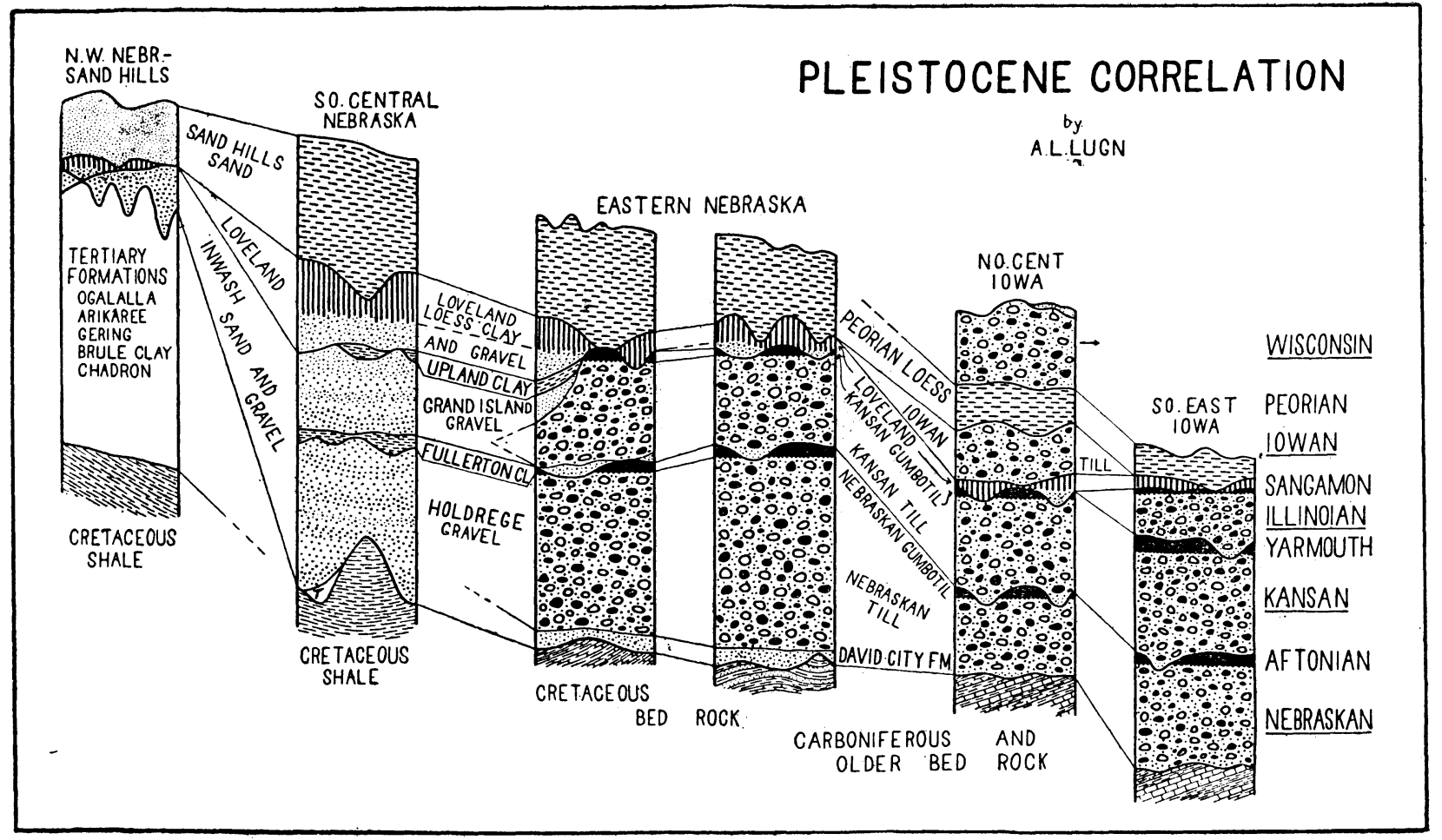

Fig. 2. Pleistocene relationships in Nebraska and Iowa. 
contains invertebrate molluscan fossils of Yarmouth age. Vertebrate fossils are likewise present.

The bed of sand and gravel which lies directly below the Upland clay ranges in thickness from about 40 to 100 feet, and is believed to be of Kansan age, being the outwash from the melting Kansan ice sheet and the contemporary inwash from other directions. It is the Grand Island formation. A persistent bed of clay and sandy silt, eight to 60 or more feet thick, separates this upper or first water-sand from the underlying or second-water gravel. This clay bed, known as the Fullerton formation, is thought to represent the lull in sedimentation during the Aftonian age. It has few exposures, as it is mostly buried at somewhat greater depth than the present topographic dissection, but it is commonly encountered in wells over large areas. The paleontology of the Fullerton formation is not well known. There are a few places where it is not present, and there are also some other localities where other local lenses of clay are encountered at other horizons, mainly within the upper water-sands or the Grand Island formation. The lower Pleistocene outwash-inwash gravel-sand formation in this area ranges from about 50 to 100 or more feet in thickness and is thought to be Nebraskan in age. It is equivalent to the David City formation and the Nebraskan till and is known as the Holdrege formation.

It should be obvious from what has been stated above that the Pleistocene geology of eastern Nebraska is much like that of western and southern Iowa. Nebraskan and Kansan tills and associated formations occur extensively in both Iowa and Nebraska. The later loess formations, Loveland, Peorian, and later loess deposits, extensive over more than half of Nebraska, are identical and more or less continuous with the same formations in Iowa and Missouri; and their relations to later glacial deposits can also be determined by tracing into the Iowan and Wisconsin till-covered areas of Iowa, and to the Illinoian, Wisconsin, and associated formations in southeastern Iowa and Illinois. Most of this important work has been done in Iowa and Illinois.

AGE OF THE LOVELAND LOESS.

It is especially significant that Kay has demonstrated the relative ages of the Iowan and Illinoian drift sheets, and has established the stratigraphic position and age of the Loveland 


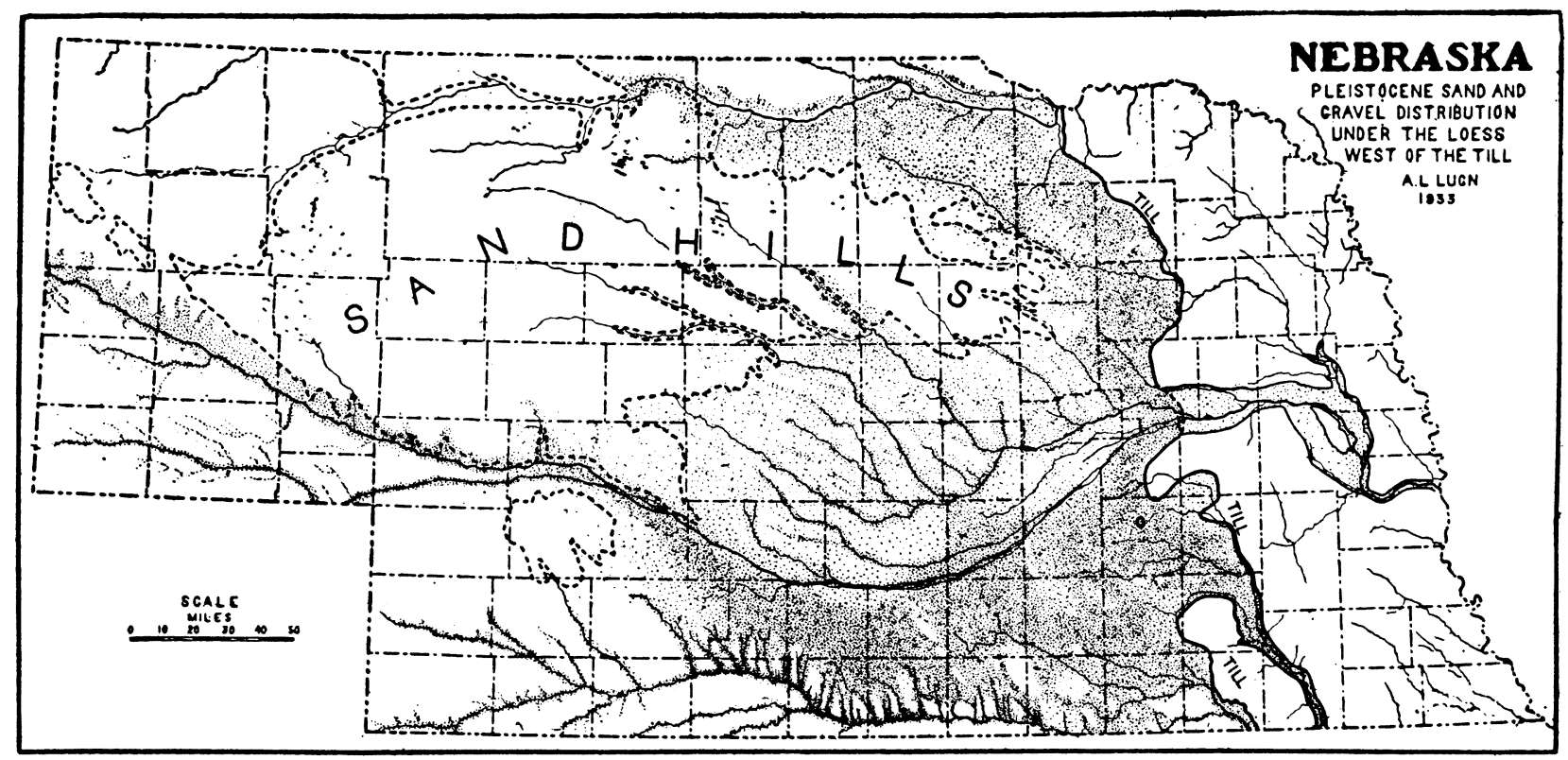

Fig. 3. The composite distribution of the fluviatile sand and gravel of Nebraskan and Kansan ages in Nebraska, west of the till border. 
loess (loess or upland phase of the Loveland formation) to be post-Illinoian-gumbotil, pre-Iowan-till in age, thus separating the older Illinoian till from the younger Iowan till by a significant loess deposit (Loveland) in Iowa. ${ }^{2}$ The correct dating of the Loveland loess in Iowa is of the greatest significance in Nebraska, as it (the Loveland formation) is the most easily recognizable and also one of the most extensive and one of the thickest Pleistocene formations in the State. It serves as a definite stratigraphic marker in eastern, south-central, northcentral, and in other areas far west in the State, where it is significantly associated with till formations and younger loess in the east and with fluvial and fluvio-glacial formations and loess deposits in the other areas.

\section{PLEISTOCENE CLASSIFICATION.}

The accompanying Pleistocene Classification table and figures 1, 2, 3, 4, 5, and 6 summarise the main facts of Pleistocene stratigraphy in Nebraska. ${ }^{3}$ It follows Kay's classifications and employs his terminology as far as that is applicable in Nebraska. It is felt, however, that the advisability of including the Iowan as a sub-stage of the Wisconsin glacial stage has not been clearly established, and that the Iowan and Peorian ages were of significant duration and should be retained in any satisfactory Pleistocene classification. ${ }^{4}$ The writer feels that field evidence exists in Nebraska, evidence of a long time of weathering and erosion which is post-Loveland pre-Peorian or Iowan in age (discussed briefly later in this paper), and that the

${ }^{2}$ Kay, G. F.: The Relative Ages of the Iowan and Illinoian Drift Sheets, This Journal, Vol. 16, pp. 497-518, 1928.

${ }^{2}$ Lugn, A. L.: The Pleistocene Geology of Nebraska, Nebr. Geol. Surv., Bull. 10, 2nd Ser., 223 pages, see pp. 27-31, 1935.

Lugn, A. L. and Wenzel, L. K.: Geology and Ground-Water Resources of South-Central Nebraska, U. S. Geol. Surv., Water Supply Paper 779, 242 pages, see pp. 15, 18, and 19, 1938.

'Kay, G. F.: Classification and Duration of the Pleistocene Period, Geol. Soc. Am., Bull., Vol. 42, pp. 425-466, 1931.

Leighton, M. M.: The Peorian Loess and the Classification of the Glacial Drift Sheets of the Mississippi Valley, Jour. Geol., Vol. 39, pp. 45-53, 1931.

Leighton, M. M.: The Naming of the Subdivisions of the Wisconsin Glacial Age, Science, n.s., Vol. 77, No. 1989, Feb. 10, p. 168, 1933.

Kay, G. F. and Leighton, M. M.: Eldoran Epoch of the Pleistocene

Period, Geol. Soc. Am., Bull., Vol. 44, pp. 669-674, 1933.

Lugn, A. L.: Op. cits.

Leverett, Frank: The Place of the Iowan Drift, Jour. Geol., Vol. 47, No. 4, pp. 398-407, 1939. 
PLEISTOCENE CLASSIFICATION

\begin{tabular}{|c|c|c|c|c|c|c|c|c|c|}
\hline \multirow{2}{*}{\multicolumn{4}{|c|}{ IOWA (G.F KAY.1931) }} & \multicolumn{6}{|c|}{ NEBRASKA (A.L.LUGN-1832-35) } \\
\hline & & & & \multicolumn{2}{|c|}{ EASTERN NEBRASKA } & \multicolumn{2}{|c|}{ SOUTH CENTRAL NEBRASKA } & \multicolumn{2}{|c|}{$\begin{array}{l}\text { SANO HILLS AND } \\
\text { WWESTERN NEBRASK } \\
\end{array}$} \\
\hline $\begin{array}{l}\text { PERIOD } \\
\text { (System) } \\
\end{array}$ & $\begin{array}{l}\text { EPOCH } \\
\text { (Series) }\end{array}$ & $\begin{array}{l}\mathrm{AGE} \\
\text { (stage) }\end{array}$ & FORMATIONS-MATERIALS & $\begin{array}{c}\text { EPOCH } \\
\text { (Series) } \\
\end{array}$ & FORMATIONS-MATERIALS & $\begin{array}{c}\text { EPOCH } \\
\text { (Series) } \\
\end{array}$ & FORMATIONS - MATERIALS & $\begin{array}{l}\text { FORMATIONS } \\
\text { MATERIALS } \\
\end{array}$ & \\
\hline \multirow{4}{*}{$\begin{array}{l}1 \\
5 \\
0 \\
5 \\
0 \\
0\end{array}$} & \multirow{4}{*}{ ELDORAN } & RECENT & $\begin{array}{l}\text { Alluvium, loess, soit } \\
\text { formation, erosion. }\end{array}$ & \multirow{6}{*}{ 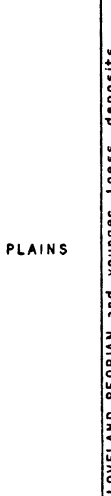 } & \multirow{3}{*}{ 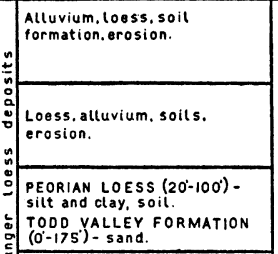 } & \multirow{6}{*}{ PLAINS } & $\begin{array}{l}\text { Alluvium. loess, soil } \\
\text { formation, erosion. }\end{array}$ & \multicolumn{2}{|l|}{$\begin{array}{l}\text { Moderate eolian } \\
\text { action, soil. }\end{array}$} \\
\hline & & WISCONSIN & $\begin{array}{l}\text { WISCONSIN TILL- boulder } \\
\text { clays sand and gravel. loess. } \\
\text { alluvium, terrace erosion. }\end{array}$ & & & & $\begin{array}{l}\text { Loess, alluvlum, soils, } \\
\text { erosion. }\end{array}$ & $\begin{array}{l}\text { Eolian } \\
\text { erosion. } \\
\text { shifting } \\
\text { sand. }\end{array}$ & \\
\hline & & PEORIAN & $\begin{array}{l}\text { PEORIAN LOESS - silt and clay. } \\
\text { residual gravel, alluvium, etc. }\end{array}$ & & & & $\begin{array}{l}\text { PEORIAN LOESS }\left(30^{\prime}-200^{\circ}\right)- \\
\text { sitt and clay, soil, thicker. } \\
\text { and coarser westward. }\end{array}$ & $\begin{array}{l}\text { SAND HILLS: } \\
\text { FORMATION: } \\
\text { OOne sand, } \\
\text { some loess. } \\
\text { some to }\end{array}$ & $\mid \begin{array}{l}2 \\
0 \\
5 \\
0 \\
\alpha \\
w \\
\end{array}$ \\
\hline & & IOWAN & $\begin{array}{l}\text { 10WAN TILL- stony boulder } \\
\text { clay, sand and gravel,residual } \\
\text { coarse gravel. loess. } \\
\text { orosion }\end{array}$ & & 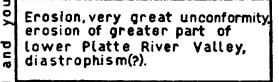 & & $\begin{array}{l}\text { Erosion. very great unconformity } \\
\text { erosion. of greater part of } \\
\text { rower Platte River valley. } \\
\text { diastrophism (?). }\end{array}$ & $\begin{array}{l}\text { Erosion, } \\
\text { soit. } \\
\text { citeilus. } \\
\text { zono" }\end{array}$ & $\begin{array}{lll}0 \\
0\end{array}$ \\
\hline \multirow{6}{*}{$\begin{array}{l}w \\
z \\
w \\
0 \\
0 \\
\leftarrow \\
0 \\
w \\
\vec{a} \\
a\end{array}$} & \multirow{2}{*}{ 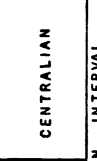 } & SANGAMON & $\begin{array}{l}\text { LOVELAND LOESS } \\
\text { ILLLNOIAN OUMBOTIL- } \\
\text { qumbotil, peat, sand and } \\
\text { gravel. }\end{array}$ & & 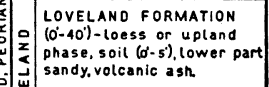 & & \multirow{2}{*}{ 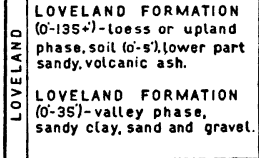 } & \multirow{2}{*}{$\begin{array}{l}\text { LOVELAND } \\
\text { FORMATION- } \\
\text { Loess } \\
\text { and } \\
\text { sand and } \\
\text { gravel. }\end{array}$} & $\mid$ \\
\hline & & ILLINOIAN & $\begin{array}{l}\text { ILLINOIAN TILL-boulder } \\
\text { clay, sand and gravel, etc. }\end{array}$ & & 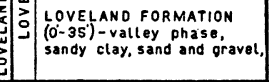 & & & & 童 \\
\hline & \multirow{2}{*}{$\begin{array}{l}2 \\
3 \\
3 \\
2 \\
5 \\
5 \\
0\end{array}$} & VARMOUTH & $\begin{array}{l}\text { KANSAN GUMBOTIL-gumbotil, } \\
\text { peat, sand and oravel. }\end{array}$ & \multirow{2}{*}{ OTTUMWAN } & 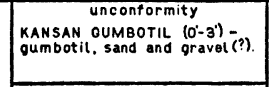 & \multirow{4}{*}{ PLATtE } & 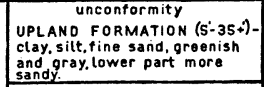 & \multirow{4}{*}{\multicolumn{2}{|c|}{ Sand and silt }} \\
\hline & & KANSAN & $\begin{array}{l}\text { KANSAN TILL- boulder clay. } \\
\text { sand and oravel, etc. }\end{array}$ & & 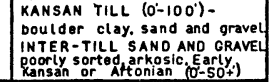 & & 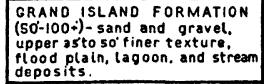 & & \\
\hline & \multirow{2}{*}{ GRANDIAN } & AFTONIAN & $\begin{array}{l}\text { NEBRASKAN OUMBOTIL- } \\
\text { oumbotil. peat, sand and } \\
\text { oravel. }\end{array}$ & \multirow{2}{*}{ GRANOIAN } & $\begin{array}{l}\text { Unconformity } \\
\left.\text { NEBRASKAN GUMBOTL (o- }{ }^{\prime}\right) \\
\text { oumbotil, peat. sand and } \\
\text { gravat. }\end{array}$ & & $\begin{array}{l}\text { Unconformity } \\
\text { FULLERTON FORMATIONG2.65 } \\
\text { clay, silt and fine sand, dark } \\
\text { color, calcareous. }\end{array}$ & & \\
\hline & & NEBRASKAN & $\begin{array}{l}\text { NEBRASKAN TILL - boulder } \\
\text { clayy sand and oravol, oarly } \\
\text { Nobrasken gravel. }\end{array}$ & & 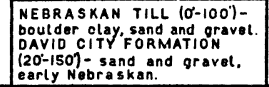 & & $\begin{array}{l}\text { HOLDREGE FORMATION (50-100) } \\
\text { sand and gravel thood plain, } \\
\text { lagoon, and stream doposits. }\end{array}$ & & \\
\hline \multicolumn{2}{|c|}{$\begin{array}{l}\text { PENEPLAIN ON } \\
\text { BED ROCKS } \\
\end{array}$} & OLOER PA & LEOZOIC ANO CARBONIFERC & & & \multicolumn{2}{|c|}{ CRETACEOUS } & ERTIARY & \\
\hline
\end{tabular}

Table 1. Pleistocene Classification. 
Peorian loess is distinctly enough separated from probable "Wisconsin" loess in this State to justify the retention of Kay's older classification. ${ }^{5}$ Some opinion has been expressed to the writer that there is some indication that this "Iowan" age of erosion may correlate with the "Canyon-cutting" cycle in the Rocky Mountains, but this point remains to be further investigated.

\section{CORRELATION WITH EUROPE.}

A pronounced tendency has developed among American geologists in recent years to attempt to correlate the American Pleistocene with that of Europe. This is evident in the writings of those who would reduce the five recognized glacial stages in America to four, as generally accepted by the majority of European students. It should be noted that not all are fully in agreement on this matter, and there can be little doubt that the best Pleistocene succession in the world occurs in the upper Mississippi Valley. Therefore, the writer would like to suggest that, in view of the great amount of detailed and precise work done by American workers in recent years on the stratigraphy of the Pleistocene, it might be more scientific and entirely in order to attempt to correlate the European Pleistocene section with that of North America.

\section{GLACIAL OR INTERGLACIAL.}

One of the most pressing questions on which agreement should soon be reached is a proper and unified understanding of what is "glacial" and what is "interglacial." The writer has become convinced that unanimity of thought and practice in this matter does not at present exist among Pleistocene geologists.

Many workers in this field, especially among Europeans, seem to consider "glacial" conditions as continuing to prevail in areas which have been abandoned by an ice sheet long after the ice has melted, in fact so long that the glacier has had time to recede nearly to the vanishing point, before strictly "interglacial" conditions are considered to have come about over the areas previously covered by ice. On the other hand, many workers, especially Americans, consider "interglacial" conditions as having begun in an area recently covered by ice, after

${ }^{5}$ Kay, G. F. and Apfel, E. T.: Pre-Illinoian Pleistocene of Iowa, Iowa Geol. Surv., Vol. 34, pp. 1-304, especially pp. 132-133, 1929. 


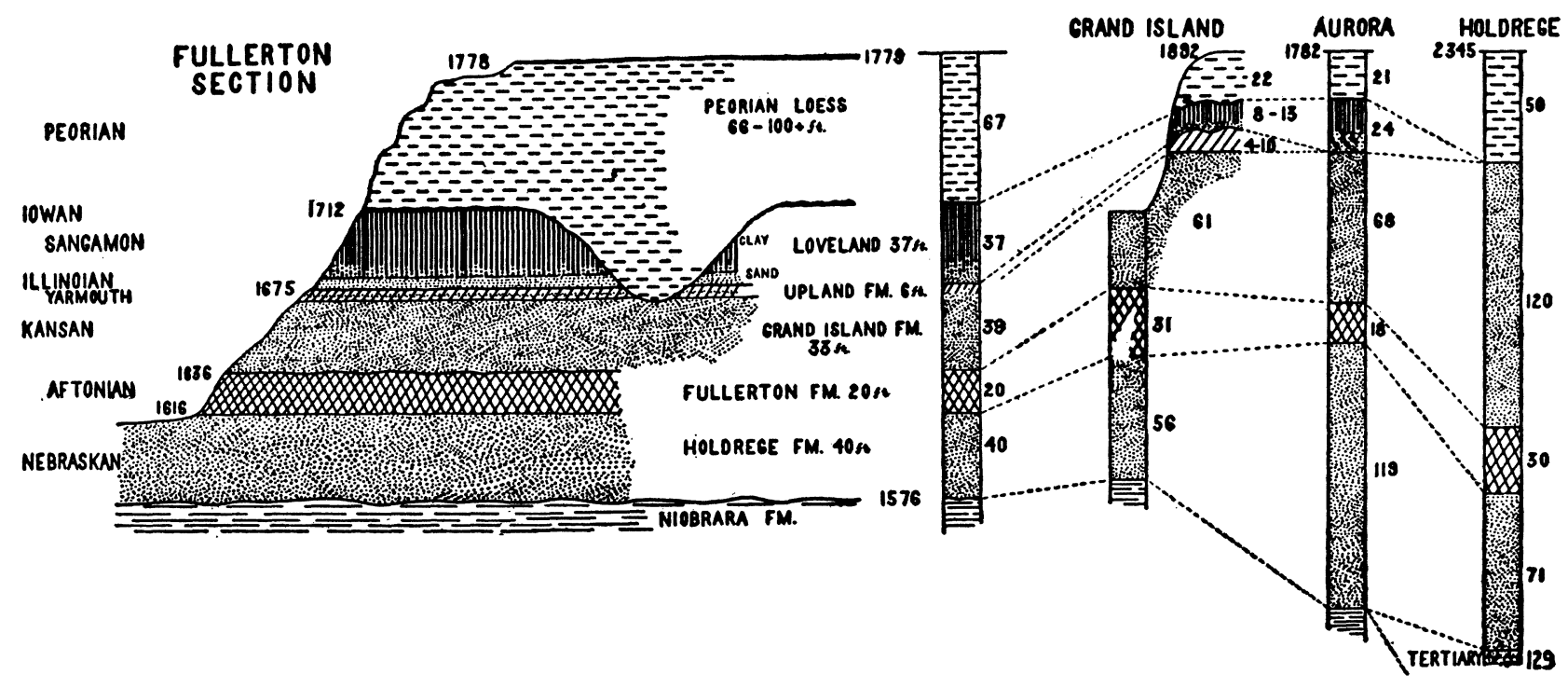

Fig. 4. Correlation of the fluviatile and loess exposure at Fullerton, Nebraska, with well logs near Fullerton, Grand Island, Aurora, and Holdrege, Nebraska. 
the ice margin has receded no more than a few scores or hundreds of miles. For example, the writer has heard it stated by at least one distinguished American authority that "interglacial" times had begun in southern Iowa after the ice had melted back no farther than to central or northern Iowa, or perhaps to the Iowa-Minnesota state line. In contrast to this opinion, others would not consider that "interglacial" conditions could exist in southern Iowa until the ice had melted back at least to central Manitoba or even farther north.

Criteria on which to decide such a question may not be easy to agree upon, and it is not improbable that determining conditions have not always been identical. The writer believes that interglacial conditions should be considered as having come about in an area lately abandoned by an ice sheet as soon as all erosion and sedimentation activities directly due to the ice or associated with the presence or nearness of the ice sheet itself cease to be active. That is, when more or less "normal" eolian and aqueous gradational processes replace those directly caused by the glacier. It is the writer's tentative opinion that this generally would necessitate a recession of the ice margin by as much as 300 to 500 miles from any location under consideration before typical interglacial conditions could prevail there. If loess transportation and deposition take place during the retreats of ice sheets and close to the wasting margins of the glaciers, then the writer would prefer to consider this eolian activity as "interglacial."

GLACIAL OR INTERGLACIAL LOESS.

This problem is closely tied up with our interpretation and dating of the loess formations. There can be little doubt that conditions favorable for the accumulation of loess in general occur during the waning stage of a glacial age, that is when the ice is abandoning the area which it had occupied at its maximum extent. It is the opinion of the writer that it seems most improbable that loess could ever have formed to any great extent in North America during the maximum advance of any of the great ice sheets; also, it is not likely that the great loess deposits could have formed during the mild times of the strictly interglacial ages; but that loess could and in all probability did form during the retreats of the great ice sheets, after the ice had melted back far enough to leave great wastes of ground 
moraine uncovered to the action of the winds, seems most probable. That it also could have formed during the advance of an ice sheet may have been possible especially in favorable situations, but generally this seems much less probable in view of the almost certain increasing humidity and precipitation. It seems that much of the apparent confusion in the literature as to whether loess is "glacial" or "interglacial" is only a confusion in terms and not a misunderstanding of facts. However, there does seem to be some strained effort on the part of a few writers to interpret certain loess as "glacial" in age, in order to bring the literature into a semblance of agreement. To be specific, the writer is of the opinion that the Peorian loess is "interglacial" if by that we mean the period of retreat of the Iowan ice sheet; but it is certainly "glacial" if we regard the period of retreat of the Iowan ice sheet as "glacial," as previously discussed. In any case, there can be little actual doubt as to when the Peorian loess really was deposited.

The above suggestions regarding the formation of loess in North America are meant to apply only here. The writer does not imply that all loess everywhere must have been formed under identical conditions. In fact, it seems almost certain that this could not have been the case. In some other parts of the world, where climate and the general wind system may be very different from here, loess may have accumulated under entirely different conditions. It seems to have been demonstrated that loess has formed in or adjacent to glaciated areas in northern India, an area more or less in the trade wind belt and also subject to the peculiarities of the monsoons, during actual glacial advance. ${ }^{6}$ This can be understood also as well as "pluvial" loess in view of the peculiarities of the winds in that part of the world, but such conditions could hardly ever have prevailed in the glaciated parts of North America in the belt of the anti-trade winds or "prevailing westerlies."

\section{DURATION OF THE GLACIAL ADVANCES.}

Another question closely related to the above problems is that of the actual duration of the individual glacial advances. Kay's estimates of the durations of the several glacial ages of the Pleistocene period are regarded as the absolute minimum time required for the actual advance and retreat of each ice

${ }^{6}$ By personal communication with Dr. Hellmut deTerra. 


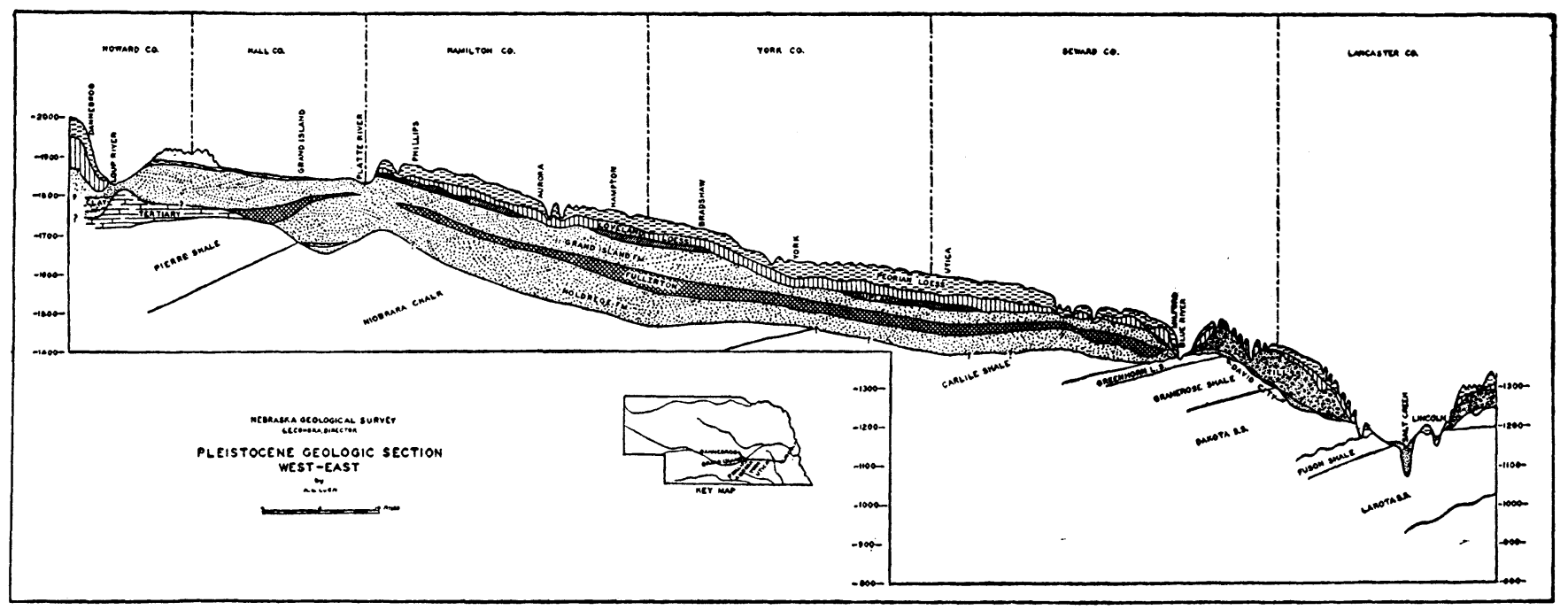

Fig. 5. Geologic profile section from Dannebrog to Lincoln, Nebraska, showing stratigraphic relations and the relationship of the Platte River to the Pleistocene fluviatile sand and gravel sheets. 
sheet. ${ }^{7}$ These estimates do not allow for any "working time," during which the ice margin remained more or less stationary, nor do they allow any interval during which the steady flow of ice from the areas of major accumulation and erosion could transport débris to build up large accumulations of till. It does not seem probable that any glacier, no matter how large, could possibly transport all of its load, terminal and ground moraine, in just one single rapid advance and retreat as implied by Kay. While there are no criteria by which to measure or estimate the rate at which till accumulates, it seems reasonable to suppose that a considerable interval of time, the working time, must be allowed for great thicknesses of till to be transported and deposited. Furthermore, the writer feels that the duration of the ice advances of the Nebraskan and Kansan glaciers, each of which accumulated more than 100 feet of till in some places in Nebraska, must have been several times as long as the duration of the advances of the minor glaciers like the Iowan or the sub-stages of the Wisconsin. The Illinoian advance must also have lasted a long time. The writer would like to suggest that the evidence of erosion and of fluviatile sedimentation in Nebraska is of such importance and magnitude as to indicate that the glacial ages may have been comparable in length to the interglacial ages as estimated by Kay, ${ }^{9}$ based on the evidence of the leaching of till and other materials. The great amount of fluviatile sand and gravel in the Holdrege and Grand Island formations lends strong support to the theory that the glacial ages were long. ${ }^{10}$ The writer has estimated that the duration of the Iowan glacial age may conservatively be placed at about 50,000 years, based on evidence of weathering and erosion in Nebraska; and Kay's estimate of 700,000 to $1,000,000$ years as the "minimum duration" of the Pleistocene period might well be doubled and still be a very conservative figure. ${ }^{11}$

Leverett ${ }^{12}$ also has clearly discerned the inadequacy of Kay's estimates on the duration of each of the glacial advances, and his estimate of 280,000 years for the combined length of all the

\footnotetext{
${ }^{7}$ Kay, G. F.: Classification and Duration of the Pleistocene Period, Geol. Soc. Am., Bull., Vol. 42, pp. 425-466, 1931.

${ }^{8}$ Lugn, A. L., Nebr. Geol. Surv., Bull. 10, p. 154, 1935.

${ }^{9}$ Kay, G. F.: Op. cit.

${ }^{10}$ Lugn, A. L.: Nebr. Geol. Surv., Bull. 10, pp. 150-155, 1935.

${ }^{11}$ Lugn, A. L.: Op. cit.

${ }^{12}$ Leverett, Frank: Op. cit.
} 
glacial ages, in contrast to Kay's total of only 30,000 years, is much more satisfactory, but in the opinion of the writer even Leverett's estimate still is far too low. Leverett's views regarding the Iowan drift also was significant in connection with the problem of Pleistocene Classification, discussed above, and his disagreement with a certain classification of the glacial deposits of North America is worthy of serious consideration. His evaluation of the Iowan and the evidence which he has presented are quite convincing that the Iowan drift definitely is much older and distinctly separate from the complex of Wisconsin deposits and moraines. As noted below, the correlation of the Iowan drift and the correct evaluation of that glacial age is one of the really important current Pleistocene problems. Long ago Calvin ${ }^{13}$ championed the cause of the Iowan drift, and a restudy both of Calvin's views and of the Iowan drift in the field would be timely.

POST-LOVELAND PRE-PEORIAN EROSION.

The question of the duration and significance of the postLoveland pre-Peorian erosion is one of the most important problems in present-day Pleistocene stratigraphy and chronology, but it is too involved to discuss in great detail in this paper. It can be properly dealt with only in the field, and many workers should coöperate in the full and complete evaluation of the field evidence. The writer has presented some evidence and stated the problem, at least, in a recent publication. ${ }^{14}$ It involves the duration of and the importance of the Iowan glacial age, the age and dating of probably the best developed set of High Plains terraces, the significance of the "Citellus" zone, and other involved and far-reaching problems.

The significant field relations which reveal the complete story of post-Loveland pre-Peorian or Iowan events in Nebraska are to be found in an area between Columbus and Plattsmouth, Nebraska, and they involve the development and history of the eastern section of the Platte River Valley, the youngest part of this drainage system.

Stratigraphic evidence indicates that prior to the deposition of the Loveland loess (Sangamon) there was no Platte River

${ }^{13}$ Calvin, Samuel: The Iowan Drift, Jour. Geol., Vol. 19, No. 7, pp. 577-602, 1911.

${ }^{14}$ Lugn, A. L.: Nebr. Geol. Surv., Bull. 10, pp. 136-158, 168-183. 
Valley from Columbus, Nebraska, east to the Missouri River. To the end of Loveland time, the Platte River and other drainages west of the glaciated area of eastern Nebraska had found outlet to the southward entirely west of the Kansan terminal moraine. The development of the eastern end of the Platte River has come about wholly in post-Loveland time.

The stream which first excavated the "Platte" Valley across the till-covered area east of Columbus to Plattsmouth at first was only a small stream tributary to the Missouri River. This creek cut its way by headward erosion steadily northwestward into the Loveland plain, gaining volume and vigor as it grew. In the vicinity of Ashland, Nebraska, it divided, one branch working more northward to become ultimately the Elkhorn River and the other branch cut headward to the northwest across Saunders County and westward to become in time the "Platte" River. This "Platte" branch occupied Todd Valley" across Saunders County from east of Morse Bluff to north of Ashland. Until this "Platte" branch succeeded in gnawing its way northwestward and westward through the impervious till deposits (Nebraskan and Kansan) and the overlying Loveland, its volume was entirely dependent on precipitation and surface drainage. The valley at first was wide and deep, from 100 to more than 150 feet deep, even deeper than the present Platte Valley in the same area, and from four to ten miles wide in some places. It was cleanly eroded and open at first.

However, in due course of time, dissection extended westward entirely through the till deposits and the Kansan terminal moraine in the vicinity of Columbus, Nebraska. Westward of this point, the volume of water in the developing Platte drainage was augmented by additions of ground water from the saturated outwash-inwash deposits of sand and gravel, mainly the Grand Island formation. This erosion into the Grand Island sand and gravel brought into the eastern Platte River a large burden of fine sand from the upper part of the formation. Fine-textured sediment was also supplied from the Loveland formation. This flood of sand and silt so overloaded the stream that it filled first the channel and ultimately the entire valley to depths of from 60 to more than 100 feet (per-

${ }^{15}$ Condra, G. E.: An Old Platte Channel, The American Geologisi, Vol. 31, pp. 361-369, 1903.

Am. Jour. Sc.-Vol. 237, No. 12, December, 1939. 


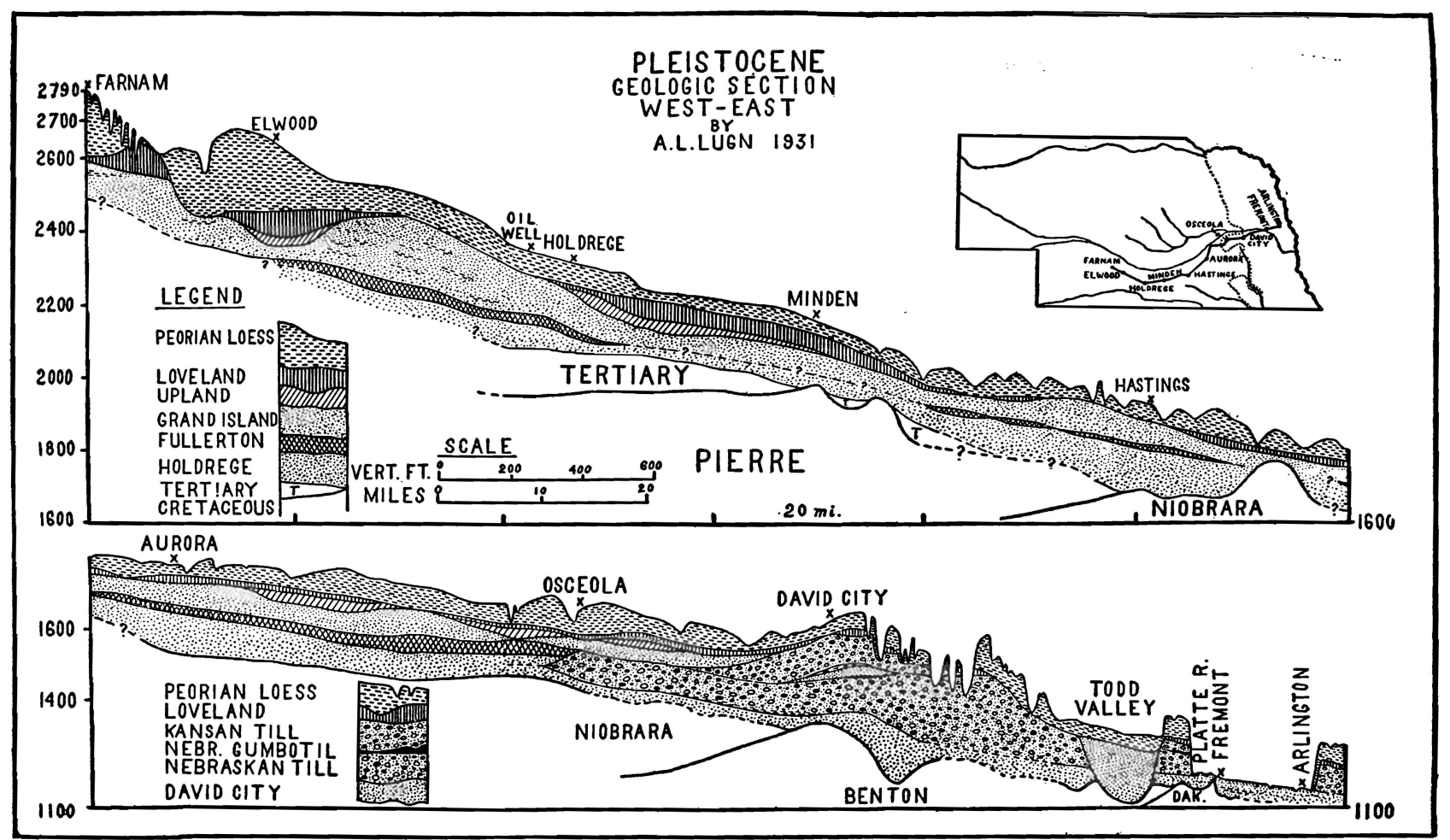

Fig. 6. Geologic profile section from Farnam to Arlington, Nebraska, showing stratigraphic relations of the fluviatile, glacial, and loess formations. 
haps as much as $\mathbf{1 9 0}$ feet at certain places in Todd Valley), and this valley fill extended from west of Columbus to Ashland, including the deep fill in Todd Valley, which has never been removed nor even much dissected.

Following the alluviation of the early Platte-Todd Valley, described above, the Platte River seems to have been diverted by piracy into the Elkhorn River Valley, to flow past the present location of Fremont to follow essentially the present course to the Missouri River at Plattsmouth. From this event, the eastern Platte River continued to work westward and southwestward, capturing and diverting more and more drainage from central and southern Nebraska, and ultimately capturing the western Platte River (the combined North and South Platte rivers) and diverting that water also from the vicinity of Kearney into the newer drainage around the great north bend of the Platte River, as it is today. From the time of the Elkhorn piracy, the growing Platte River was able to deepen its valley or rather to scour out a new valley within the old one from west of Columbus by eroding and cutting away the earlier valley fill of fine sand that had come into it during the Todd Valley stage. The uneroded remnants of the older valley fill ('Todd Valley age) of fine sand and gravel were left and still remain as terraces from 50 to 80 feet above the level of drainage. These terrace remnants, like Shell Creek Terrace east of Columbus and Todd Valley Terrace in Saunders County, are sometimes referred to as Iowan terraces because all of the postLoveland events described above, including the erosion, alluviation, and abandonment of Todd Valley, and also the erosion of the new valley past Fremont to the Elkhorn, took place before the deposition of any "Peorian" loess. Accordant terraces, apparently correlative with the Shell Creek and Todd Valley levels, occur more or less throughout the Platte River Valley across the State and also in other valleys in Nebraska and elsewhere throughout the Great Plains.

Following the Platte River Valley development across eastern Nebraska, sketched above, the mantle of Peorian loess was deposited to thicknesses of 15 to 30 feet over most of eastern Nebraska and to greater thicknesses farther west. Being a wind deposit, the loess was laid down more or less evenly on the tablelands, on valley slopes, on the terraces like Shell Creek Terrace, over the Todd Valley fill, and even over the floodplains of the Platte, Loup, and other drainages. 
All of the post-Loveland pre-Peorian history, sketched so briefly above, should be convincing evidence that the interval between Loveland loess or Sangamon time and Peorian time was of long duration, and that the Iowan stage of glaciation is represented in Nebraska by great and profound erosion, interesting and important topographic developments, and significant. drainage adjustments.

\section{GEOMORPHOLOGY OF THE GREAT PLAINS AND \\ PLEISTOCENE HISTORY.}

Pleistocene diastrophism is pretty well demonstrated, and some of the details are more or less revealed by evidence in Nebraska and elsewhere by terraces and the general physiographic features of the northern Great Plains. Pleistocene geologists and physiographers should give more attention to the interpretation of peneplain and terrace levels in the Rocky Mountains and High Plains in relation to the fluviatile Pleistocene deposits to the eastward. ${ }^{16}$ The geomorphology of the Great Plains and Rocky Mountains eventually will reveal much of the Pleistocene story. ${ }^{17}$ In this connection, it should not be lost sight of that glacial rivers, that is Pleistocene rivers flowing from areas being vigorously glaciated, aggraded their valleys and floodplains during ice advances, and deepened their channels to new "grades" during the interglacial ages when they were not overloaded. ${ }^{18}$ This, of course, is the case with all inland rivers which for one reason or another become overloaded with sediment regardless of the supply of water. On the other hand, any river carrying an abundance of water but not overloaded with sediment will scour the channel. It is believed that the development of the major drainages across the Great Plains during and following the Pleistocene were influenced by both diastrophic and climatic control. Climatic control is thought to have been most important in the periodic overloading of the rivers with sediment and causing them to aggrade the floodplains, especially during the glacial ages; but

${ }^{16}$ Lugn, A. L.: Nebr. Geol. Surv., Bull. 10, pp. 168-183, 1935.

${ }^{17}$ Lugn, A. L.: Relation of Cycles of Erosion to Cycles of Sedimentation in the Rocky Mountains and the Northern Great Plains, Geol. Soc. Am., Proc. for 1935, June, 1936.

${ }^{18}$ Chamberlin, T. C. and Salisbury, R. D.: Geology, Vol. 1, pp. 186-187, 208. Henry Holt and Co., (3 vols.), New York, 1904-06, Revised ed., 1909.

Lobeck, A. K.: Geomorphology, pp. 167, 221, New York, 1939. 
diastrophism probably has been fundamentally responsible for the attainment of new and successively lower "grades" during the entire time.

A river which drains through a mountain valley being vigorously glaciated with an active glacier at the head almost without exception aggrades its valley by building up a valley train of sediment derived from the glacial mill. When the glacier disappears and the supply of sediment is largely cut off, the river, even though reduced in volume, is no longer overloaded and can dissect the alluvial fill and adjust itself to a new and lower "grade" even without diastrophic influence. The Rocky Mountains of Colorado and Wyoming were vigorously glaciated several times during the Pleistocene. It seems logical that the rivers which flowed eastward across the High Plains, like the North and South Platte rivers, during the epochs of maximum ice action must have been overloaded with sediment and hence aggrading during the glacial ages and not overloaded and hence eroding and scouring during the interglacial ages. ${ }^{19}$

On the other hand, rivers which drained from areas of less severe temperatures and for the most part unglaciated but experiencing increased humidity and precipitation during glacial ages, would discharge increased volumes of water without being overloaded with sediment. Such drainages would tend to erode and deepen channels during the glacial ages and to widen floodplains and alluviate during interglacial ages, the reverse of the behavior of the drainages from vigorously glaciated regions. This was likely true of certain rivers in the more or less arid southwestern United States during the Pleistocene period. Fiedler and $\mathrm{Nye}^{20}$ in discussing the relation of physiographic history to glaciation state:

"During a relatively humid period the flow of the streams would be increased. At the same time there would be more vegetation in and near the mountains and a lower limit of timber, and hence less erosion of the mountain slopes and less

${ }^{19}$ Lugn, A. L.: Nebr. Geol. Surv., Bull. 10, 168-183, 1935.

Alden, Wm. C.: Physiography and Glacial Geology of Eastern Montana and Adjacent Areas, U. S. Geol. Surv., Prof. P. 174, 1932.

Powers, Wm. E.: Physiographic History of the Upper Arkansas River Valley and the Royal Gorge, Colorado, Jour. Geol., Vol. 43, No. 2, pp. 184199, 1935.

${ }^{20}$ Fiedler, Albert G. and Nye, S. Spencer: Geology and Ground-Water Resources of the Roswell Artesian Basin, New Mexico, U. S. Geol. Surv., Water Supply Paper 639, p. 111, 1933. 
material contributed to the streams. Therefore, the streams would erode, especially in the soft materials of the alluvial basin. The trenching would be most rapid at the beginning of the humid period and would gradually decrease with lowering gradient. Later the streams would tend to widen their channels, especially in the lower parts of their courses. With change to more arid conditions the vegetation would decrease, the lower edge of the timber would retreat upward, and the partial loss of the protective mat of vegetation would permit increased erosion of the upland slopes. With increase in load and decrease in the volume of water the streams would be unable to transport all of the material supplied to them, and would aggrade, especially in the arid alluvial basin. Thus the almost continuous downcutting of the streams in the mountains and the alternate periods of erosion and sedimentation by the streams in and near the alluvial basin may well have been the result of climatic changes.

"The five stages of downcutting by the streams after the completion of the Llano Estacado may perhaps be correlated with the five glacial stages recognized in the United States ..." A detailed table follows in which a definite correlation of events is suggested.

Albritton and Bryan ${ }^{21}$ have recently expressed a rather different interpretation in regard to the climatic control of erosion and sedimentation in regions of arid climate. They state, "It is a well-established working hypothesis that in an arid climate and in areas of ephemeral and intermittent streams aggradation of valley floors occurs in periods of relative humidity and erosion by channeling occurs in periods of relative aridity."

Also in contrast to the behavior of inland Pleistocene rivers flowing from glaciated regions, the Pleistocene coastal plain rivers deepened their valleys and scoured their channels during the glacial ages, probably because of the lowered water level in the ocean at their mouths which obviously caused a steepening of the gradients. Coastal plain rivers aggraded and filled their

${ }^{21}$ Albritton, Claude C. Jr., and Bryan, Kirk: Quaternary Stratigraphy in the Davis Mountains, Trans-Pecos, Texas, Geol. Soc. Am., Bull., Vol. 50, pp. 1423-1474, 1939; See also, Wanless, Harold R. and Shepard, Francis P.: Sea Level and Climatic Changes Related to Late Paleozoic Cycles, Geol. Soc. Am., Bull., Vol. 47, pp. 1177-1206, especially pp. 1191-1193, 1198-1199, 1936. 
valleys more or less during the interglacial ages. ${ }^{22}$ Therefore it will be most difficult if not impossible to correlate or rather to match inland terraces in regions influenced by glaciation, as suggested above, with coastal plain terraces formed during the Pleistocene period. The writer is well aware that the problems of the geomorphology of terraces are much more complicated and involved than seems to be suggested in this brief discussion, but it is hoped that these few hints may stimulate thought and research in this interesting field.

SOURCES OF LOESS MATERIALS.

Another involved problem of the Pleistocene which is too big to deal with fully here and still too important to neglect is that of the sources of the great loess deposits of this continent. The writer ${ }^{23}$ recently has presented evidence in publication to the effect that most or at least a very large part of the loess has been derived by the reworking mainly of Tertiary and the older Pleistocene formations in large areas over the High Plains. River valley floodplains are wholly inadequate to have supplied the quantity and to have been responsible for the distribution of the loess, at least in Nebraska and other midwestern states. Floodplains have, of course, made contributions to the sum total of loess, and this is not meant to imply that in some parts of the world, especially in Europe, floodplains may not have been the main sources of most of the loess. Most of the Peorian and later loess in Nebraska has come from the Sand Hills Region located in the central and central western part of the State. It is an area of about 20,000 square miles, and the dune sand has been derived by wind action mostly from the older Tertiary (Ogallala) sandy formations. Indurated cores of Tertiary sandstone underlie the dune sand in nearly all of the hills and ridges. The dune sand is the material left behind after the fine silt and clay had been sifted out and carried

${ }^{22}$ Mac Clintock, Paul and Richards, H. G.: Correlation of Late Pleistocene Marine and Glacial Deposits of New Jersey and New York, Geol. Soc. Am., Bull., Vol. 47, pp. 292-294, 1936.

Wentworth, C. K.: Sand and Gravel Resources of the Coastal Plain of Virginia, Va. Geol. Surv., Bull. 32, 146 pages, 1932.

See also numerous references cited in the above papers.

${ }^{23}$ Lugn, A. L.: Nebr. Geol. Surv., Bull. 10, pp. 158-167. See also, Leighton, M. M.: Geology of Soil Drifting on the Great Plains, Scientific Monthly, Vol. 46, pp. 22-23, July, 1938; and Lobeck, A. K.: Geomorphology, pp. 389, 393, New York, 1939. 
eastward and southeastward to become the yellowish and yellow-gray loess, which was spread over a fan-shaped area of tens of thousands of square miles in southern and eastern Nebraska and areas farther eastward. The Peorian loess becomes thicker, lighter in color, and coarser in texture from east to west and from southeast to northwest, and in some areas it can be seen actually to grade into the dune sand of the Sand Hills formation of the Sand Hills Region, from which most of the Peorian loess of Nebraska is believed to have come. This textural gradation toward the source areas is now supported by additional field and laboratory evidence based on work not yet completed. Samples of the loess have been analyzed by the best accepted laboratory methods and have been found to become coarser toward the source areas; heavy minerals are present only comparatively near the source areas, and only light and flaky minerals have been carried long distances from the sources, and these become finer in texture away from the source localities. The calcium carbonate content of the loess also has been studied quantitatively and has yielded much evidence on the conditions prevailing during the deposition of the loess. It is believed that the "lime" content reveals more or less of the climatic conditions existing at the time of deposition, extent and nature of leaching contemporaneous with formation, ground water conditions, and also sources of the material itself. A complete report of all of this work is too long and complicated to present in this paper, but it will be published in the near future. ${ }^{24}$

There are a number of other sand hill source areas for the loess of Nebraska and other states. Loess material at different times has been derived from exposed Cretaceous shale areas in Colorado and Wyoming, and also from Tertiary High Plains areas in Colorado, Wyoming, and western Nebraska. Recent dust storms have produced blow-out depressions, a number of feet deep and many acres in extent, in exposed Cretaceous and Tertiary formations, especially in South Dakota, western Kansas, and in eastern Colorado. Blow-out depressions, still mostly undrained, as much as $\mathbf{4 0}$ feet deep and up to two square miles in extent, have been formed by wind action in the past, in the exposed Tertiary silty and sandy beds of the High Plains tableland areas of western Nebraska and adjoining regions.

${ }^{24}$ Maher, John C.: The Calcium Carbonate Content of the Peorian Luess of Nebraska, unpublished thesis, University of Nebraska Library, 1937. 
These depressions in some areas are eroded into the upper part of the Ogallala group, and their depth of about 40 feet is limited by a bed of coarse, heavy gravel (the Sidney gravel) in the Ogallala. The gravel limits the depth of the blow outs because it is too coarse in texture to be handled by the wind, but the overlying beds are of fine textured silt and fine sand, which the wind is competent to erode and rework. A few small sand dunes or hummocks occur in some of the larger depressions, but the eroded areas for the most part are yet too small to have become sand hills areas.

At present, many of these depressions have only subsurface drainage. Solution action by percolating water has no doubt aided in the solution of the cementing mineral matter, thereby aiding in loosening the Tertiary silt and sand and facilitating the deepening of the depressions, once they were started by wind erosion. A number of the blow-out depressions have acquired drainage outlets in the normal course of the local physiographic development. Eolian erosion seems still to be a factor in the physiographic development of the High Plains, and the evidence of recent wind action is believed to indicate the nature of the agents and processes which produced the Peorian and other ancient loesses. Eolian action over Cretaceous limy shale areas, especially in South Dakota, seems to have materially affected the calcium carbonate content of the loess in northeastern Nebraska and adjacent regions where the "lime" content is unusually high.

Other more or less local source areas for loess are known east of Nebraska. For example, the evidence is quite conclusive, that much of the Peorian loess of eastern and southeastern Iowa was blown from the Iowan till area in north central Iowa. In fact, the stony, sandy, and bouldery residue that occurs on the thin Iowan till, and which is all that remains of the Iowan till sheet in many places, was in part produced by eolian action. The absence of dunes, eolian sand drifts, or even a mantle of dune sand on the Iowan till is probably because of greater precipitation and more vigorous aqueous erosion over the Iowan area than in areas farther west, as in the Sand Hills of Nebraska, and perhaps also to the smaller proportion of medium and fine sand to very fine sand in till, than usually occurs in the Tertiary formations under the Sand Hills Region of Nebraska. This denudation of the Iowan till area in Iowa of necessity took place in post-Iowan or late Iowan time 
(Peorian), depending on the understanding of the terms "glacial" and "interglacial." Loess deposition could not have begun in this area earlier than in late Iowan time, after the ice had melted back far enough to have uncovered the area to wind action. It is important to understand if this should be regarded as "glacial" or "interglacial" time, as previously discussed in this paper.

RIVER VALLEYS AND LOESS DEPOSITION.

Depressions and large river valleys like the Missouri River Valley served as sedimentation traps for the loess dust as it was swept across the country by the westerly winds. The dust that was kept suspended and in motion across the level tablelands and prairies had a tendency to settle out through the quieter atmosphere in the valleys, as it was swept out over the valley depressions, especially if they trended more or less at right angles to the prevailing wind direction. The writer has had the unusual experience of observing a great dust storm sweep eastward over the level prairie of eastern Nebraska out across the Missouri Valley. Much of the dust, in fact most of it, seemed to be carried on across the valley and beyond over the level tablelands of Iowa, but a considerable amount could be seen to settle in the valley. Of course, this was kept in suspension for some time by the local turbulence of the atmosphere in the valley, but there can be no doubt that the valley and its side slopes became the ultimate resting places for large quantities of the dust, which had been transported for perhaps hundreds of miles across Nebraska. It is natural that a great thickness and a large quantity of this material would be trapped in the Missouri River Valley, and that more of it would drift against the east bluff, the Iowa side, than would find permanent lodgment on the west side. Of course, floodplain silt and dust would be stirred up by the local turbulence and winds in the valley, and at times this would augment the general supply of eolian silt and clay from other regions.

The whirlwinds and dust clouds that can be observed originating on the floodplain of the Missouri River some times are impressive, and there is good reason why many have believed that river valley alluvium is the main source of loess dust, but all of this is not nearly so impressive as great billowing dust clouds, thousands of feet high, rolling over the plains and across wide valleys. However, the amount of loess derived from the 
floodplains of rivers may have been and no doubt was large. The mud flats and wide floodplains along drainages over recently glaciated areas of ground moraine would be ideal local sources for eolian dust. The writer has no desire to minimize the importance of this source of loess material, but it seems quite evident that the quantitative importance of sand hills and other areas of eolian erosion, regionally considered, in general has been neglected and underestimated.

\section{DUST STORMS.}

Additional evidence in support of the "regional source area" theory for the origin of loess is supplied by the numerous great dust storms of 1934, 1935, and more recently. For example, during the great dust storm of March 20 to 22, 1935, the geology department of the University of Wichita, Wichita, Kansas, "weighed" the atmosphere, on March 20, and estimated that $5,000,000$ tons of dust were suspended over the 30 square mile city of Wichita area, in a layer only one mile thick at $11: 00$ A.M. However, the dust extended upward to a height of more than 12,000 feet, according to air transport pilots, so the above estimate appears to be very conservative. The source area for most of the dust of this storm was localized in southeastern Colorado, more than 250 miles west of Wichita. Dust from this area seems to have been deposited, at least locally to some extent, at most places across Kansas and eastward, and the great dust cloud eventually reached the Atlantic coast, nearly 1,500 miles from the source area in Colorado, where eolian blow outs, sand dunes, and dust hummocks were forming. A more complete discussion of the dust storms and the mechanics of loess sedimentation is in preparation for publication soon.

$$
\text { THE "CITEllus" zone. }
$$

The Citellus zone supplies one of the most intriguing problems of present day Pleistocene geology, especially since it also is so closely related to the problem of the antiquity of ancient man in North America. The Loveland soil (developed on the loess phase of the Loveland formation-Sangamon age) and a few feet of the basal part of the Peorian loess recently have been found to contain an abundant and interesting Pleistocene mammalian fauna. Fossils in this zone were discovered to be abundant in Lincoln County, Nebraska, especially south of the 


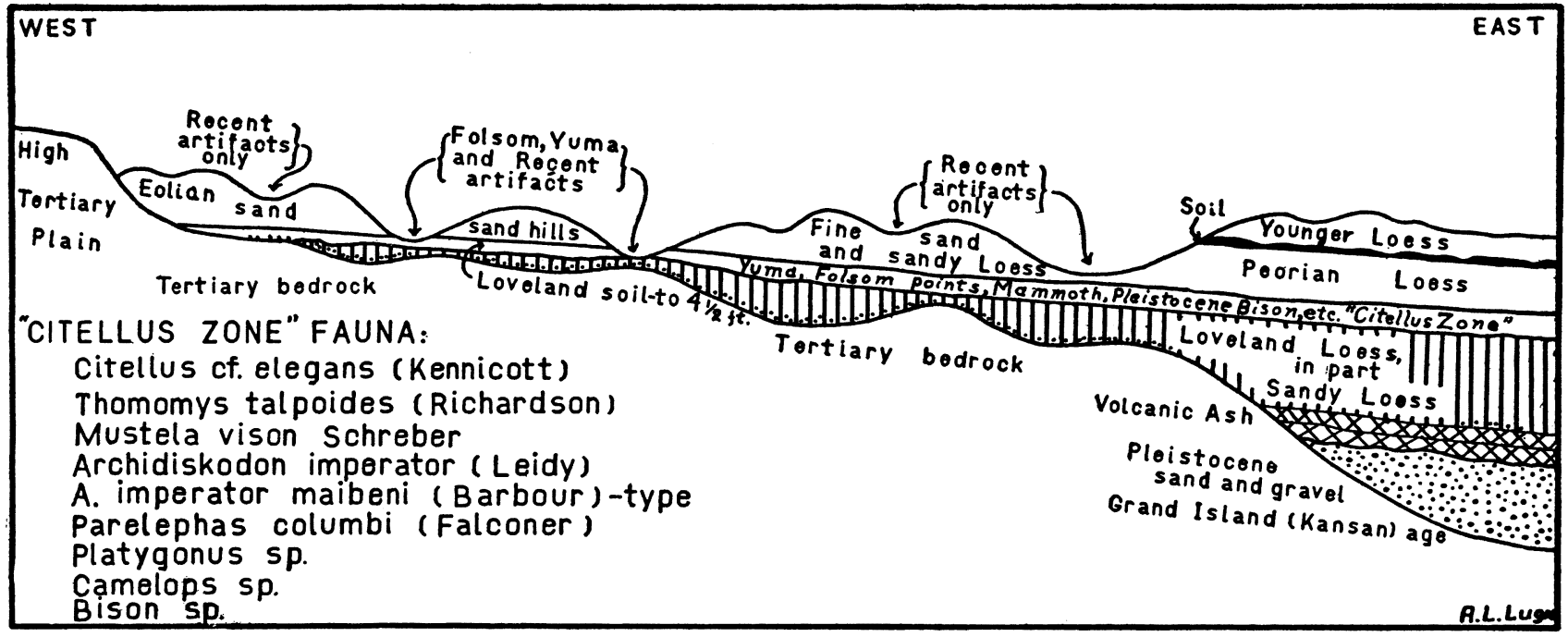

Fig. 7. The geologic relationships of the Citellus faunal zone. 
Platte River, and nearly all vertebrate collections from this area have been obtained from this zone. Many fossil locations in Lincoln County and also in other counties have been explored by collecting parties from the Nebraska State Museum, and in the summer of 1934 Mr. C. Bertrand Schultz and Mr. Thompson M. Stout revisited all known sites, checking stratigraphic horizons and further verifying the vertical limits of fossil occurrences. Mr. Schultz ${ }^{25}$ is quoted below:

"There does not seem to be a sharp division between the upper part of the soil zone and the basal part of the Peorian. The soil zone and the Peorian gradational layer are here grouped together and called the Citellus faunal zone because of the abundance of fossil remains of the ground squirrel Citellus found in this zone. The importance of this faunal zone lies in the fact that it furnishes a definitely dated late-Pleistocene fauna. The Citellus faunal zone is post-Loveland and prePeorian or early Peorian. This zone as it has been investigated, has definitely yielded the remains of :

Citellus cf. elegans (Kennicott)

Thomomys talpoides (Richardson)

Mustela vison Schreber

Archidiskodon imperator (Leidy)

Archidiskodon imperator maibeni (Barbour)-Type

Parelephas columbi (Falconer)

Platygonus sp.

Camelops sp.

Bison sp."

It might be added that the age during which the animals represented by these fossils might well have included from the late Sangamon, the more humid Iowan age, and the opening decades or centuries of the drier Peorian interglacial age.

The above assemblage of fossils has also been found at many places beyond the occurrence of typical Loveland formation associated with a poorly developed soil layer on materials that are not typical Loveland, even though the underlying older materials are often reddish in color. The parent material for this soil zone, in some places, is disintegrated Tertiary rock,

${ }^{25}$ Lugn, A. L. and Schultz, C. Bertrand: The Geology and Mammalian Fauna of the Pleistocene of Nebraska, Nebr. State Mus., Vol. I, Bull. 41, pp. 359-360, 1934. 
and, at other places, it is probably earlier Pleistocene deposits. This zone with its fossils is usually buried under eolian dune sand in the Sand Hills Region north of the Platte River and in the sandy area in Lincoln County and in other similar areas in Chase and Dundy counties south of the Platte River. There is strong and convincing evidence that this old soil in many places had been developed and buried under more or less Peorian loess, including the contained Citellus fossils, and later the wind has removed the overlying Peorian loess or much of it, and that still later dune sand has drifted in over the more or less exposed old soil.

The most striking fact about this Citellus zone is that human artifacts appear to occur in it at many places in western Nebraska, and apparently also in Colorado. The artifacts are of the Folsom and Yuma types, and are found in the Sand Hills Region and in other places only after the sand has been removed, usually in large blow outs, and the old soil zone exposed and disturbed. The geological relationships of the Citellus zone are shown in Fig. 7. It is a significant fact that the artifacts have been found associated with the Citellus fauna more often than not, and there seems to be little room for doubt but that the artifacts really are associated in place with the fossils of this zone. The Sand Hills formation of dune sand is believed to be largely of Peorian age. However, evidence is quite convincing that several periods of eolian activity are represented in the geomorphology of the Sand Hills Region in Nebraska. All of this lends support to the assignment of great antiquity to the Citellus zone, the old soil, and to the contained artifacts.

It might be objected that the Sand Hills formation, or at least parts of it which overlie the artifact sites, might be of later age. This is a reasonable and conservative objection. There is at least one post-Peorian loess formation, also in the vicinity of North Platte; and there is at least one younger old soil below the present soil and above the Loveland soil, also in the same area and throughout a very large region in western Nebraska and adjoining areas in Colorado and Kansas. However, at no place, so far known, have Citellus zone fossils ever been found in any of the overlying soils or loess deposits. Likewise, neither Folsom nor Yuma artifacts have so far been found in the younger and higher soils or loesses nor in the dune sand. And, most significant of all, the Folsom and Yuma 
artifacts are usually found associated with fossils of the Citellus zone. Several hundred artifacts from sites presumably belonging to this zone have been collected. Practically all of the field work that has been done on this problem since 1934 has tended to strengthen the interpretation stated above, and the conviction of the Pleistocene antiquity of this zone has also been strengthened. The multiplicity of old soil zones in the Sand Hills Region of Nebraska as well as the reality of the Citellus zone in the same area have been more convincingly demonstrated than ever before. The evidence in support of a Pleistocene (Ice Age) antiquity for man in Nebraska seems to be stronger now than ever before. ${ }^{26}$

\section{THE PROBLEM OF ANIMAL SURVIVAL.}

Some have urged that Pleistocene mammals may have survived into Recent times, at least in some places where the fossil remains are entombed in deposits which may be either Recent or as old as Pleistocene, but which cannot convincingly be demonstrated to be as old as Pleistocene. It may be true that in certain areas, "havens of refuge" like the Great Basin, some Pleistocene forms may have survived much longer than in other areas, but so far in more than twelve years of close study of these problems, the writer has not seen a single case of Pleistocene fossils occurring in Recent sedimentary deposits in Nebraska or adjoining states. The Pleistocene stratigraphy of Nebraska is sufficiently understood now to warrant acceptance of definite faunal succession in the Pleistocene period, and Recent deposits are distinctly enough separated from the older Pleistocene formations to be generally distinguishable. There is a definite faunal succession in the Pleistocene, and there was organic evolution in that period which can be recognized. ${ }^{27}$

${ }^{26}$ Barbour, E. H. and Schultz, C. Bertrand: Paleontologic and Geologic Consideration of Early Man in Nebraska, Nebr. State Mus., Vol. I, Bull. 45, pp. 431-440, 1936.

Mac Clintock, Paul, Barbour, E. H., Schultz, C. Bertrand and Lugn, A. L.: A Pleistocene Lake in the White River Valley, Am. Naturalist, Vol. 70, pp. 346-360, 1936.

Mac Clintock, Paul: Investigation of the Geology of the Yuma-Folsom Sites in Western Nebraska, Carnegie Inst. Wash. Year Book No. 34, pp. 318$319,1935$.

Schultz, C. Bertrand: The First Americans, Natural History, Vol. 42, pp. 346-356, December, 1938.

${ }^{27}$ Lugn, A. L. and Schultz, C. Bertrand: Op. cit. 
The burden of proof that Pleistocene animals survived into the Recent rests on those who make such claims, and they must demonstrate beyond possibility of doubt that any and all deposits which contain "Pleistocene" remains are not of Pleistocene antiquity.

\section{AFtonian (?) FAUNA.}

Certain faunas from deposits of sand and gravel in eastern Nebraska and western Iowa, mainly along the Missouri Valley, have long been accepted as type faunas for the Aftonian, on the assumption that the deposits were certainly known to be of that age. ${ }^{28}$ The writer has become convinced by evidence in the field that there are several ages of deposits present in and along the Missouri Valley both in Nebraska and Iowa, and several of these have contributed to the so-called "Aftonian" fauna. Some of these deposits are as old as Aftonian, but others are as late as Yarmouth or even Loveland (Illinoian ${ }^{29}$ or Sangamon). There now seems to be little doubt but that much of the old "Aftonian" fauna from the Missouri Valley is not only not as old as Aftonian, but some of it may be as young as Loveland loess (Sangamon) or even Citellus zone. In view of the rapidly growing body of evidence, it is now absolutely necessary to reopen the question of the age of these deposits along and in the Missouri Valley which have so long been accepted as containing the type Aftonian faunas. It may not be out of order to suggest that a thoroughgoing restudy of the age of the gravels in the vicinity of Thayer and Afton, Iowa, would likewise be highly desirable. Such restudies will likely result in greatly revised ideas regarding just what constitutes the Aftonian fauna. ${ }^{30}$ It will quite certainly be very different from the assemblage heretofore accepted, and it will contain many forms previously regarded as Pliocene for the

${ }^{28}$ Calvin, Samuel: Aftonian Mammalian Fauna, Geol. Soc. Am., Bull., Vol. 20, pp. 341-356, 1909.

-: Aftonian Mammalian Fauna II, Geol. Soc. Am., Bull., Vol. 22, pp. 207-216, 1911.

Shimek, B.: Aftonian Sands and Gravels in Western Iowa, Geol. Soc. Am., Bull., Vol. 20, pp. 399-408, 1909.

Also other papers by both Calvin and Shimek.

${ }^{29}$ The lower sand and gravel phase of the Loveland may be as old as Illinoian.

${ }^{30}$ Barbour, E. H. and Schultz, C. Bertrand: An Early Pleistocene Fauna From Nebraska, Am. Mus. Nov., No. 942, pp. 1-10, 1937. 
simple reason that they were regarded as too primitive to belong to an Aftonian fauna, since, as was stated above, the so-called "Aftonian" fauna actually contained many forms as late as Yarmouth and Loveland ages. ${ }^{31}$

\section{ANTIQUITY OF VARVED SEDIMENTS.}

The last Pleistocene problem which the writer wishes to call attention to, is the urgent need of much closer scrutiny of the principles of varve chronology as applied to Pleistocene problems in general and to the "man" problem in particular. Varve deposits are definitely associated with artifacts of undoubtedly great antiquity, ${ }^{32}$ but also evidence has come to light recently that varves may be formed in sediments not in any way associated with glaciation. ${ }^{33}$ All that is required, apparently, is a lake or pond which remains frozen over more or less continuously each winter season and which contains quiet water, that is a pond or lake with no flow during the time of the formation of the "winter" layer. Several such old ponds are known near Cambridge, Nebraska. These ponds were a part of the ditch of a now abandoned irrigation system, and they contain varve deposits which record perfectly the sedimentation chronology, with winter and summer layers, for the years these ponds contained water. The origin and formation of the varve colloids require more complete study.

\section{CONCLUSIONS.}

Thus it is evident that there are many problems and questions concerning both details and broad generalizations in Pleistocene stratigraphy that should be studied in greater detail than ever before, before there can be any sure agreement on all of the details of Pleistocene chronology. Important field evi-

\footnotetext{
${ }^{31}$ Since the preparation of this manuscript, Mr. Jack Graham, a graduate student at the State University of Iowa, has begun a thorough restudy of the Aftonian fauna in Iowa and Nebraska under the joint direction of G. F. Kay, University of Iowa, and C. Bertrand Schultz and the writer, University of Nebraska.

${ }^{32}$ Schultz, C. Bertrand: Op. cit.

${ }^{33}$ Mac Clintock, Paul: Investigations on the Varve Sediments in Western Nebraska and South Dakota, Carnegie Inst. Wash., Year Book, No. 35, pp. 325-326, 1936.
}

Am. Jour. Sc.-Vol. 237, No. 12, December, 1939. 
dence is available pertaining to many of these unsettled questions within the borders of the State of Nebraska. Also, it is still too early to accept as final any certain Pleistocene classification, and there has been too great a tendency recently to accept as settled most of the large problems of Pleistocene geology. Nothing could be farther from the real truth. Pleistocene geology is still, as it has been, in the "experimental" stage.

Department of Geology,

UNIVERSITY OF NEBRASKa, Lincoly, Nebraska. 